\title{
Research Concerning the Economic Efficiency of Four Species of Medicinal Plants Grown in the Western Part of Transylvanian Plaine
}

\author{
Simona DUDA, Liviu Al. MĂRGHITAȘ, Dan DEZMIREAN and Otilia BOBIŞ* \\ Department of Technological Sciences - Animal Husbandry, \\ University of Agricultural Sciences and Veterinary Medicine Cluj-Napoca, Romania \\ *Corresponding author: obobis@usamvcluj.ro \\ Bulletin USAMV series Agriculture 72(2)/2015 \\ Print ISSN 1843-5246; Electronic ISSN 1843-5386 \\ DOI 10.15835/buasvmcn-agr: 11587
}

\begin{abstract}
In this paper we present the economic efficiency of four species of medicinal plants grown in the experimental field of Jucu, belonging to the University of Agricultural Sciences and Veterinary Medicine, Cluj-Napoca.

Through the conducted research we wish to emphasize the cultivation profitability of the four studied species of medicinal plants.

Economic efficiency was established by calculating the following economic indicators: its output per hectare, production value, average price recovery, cost of production, valorization cost, the cost per unit of output, gross margin and gross margin change.

We evaluated from an economic profitability point of view in terms of 2014, the 4 studied crops. Expenditure on maintenance, harvesting and conditioning of the production was balanced against the income earned by selling the raw materials plants.

Technological sheets were developed, income and expenditure budgets and cost-benefit analysis was done for each species.

It appears that the largest share of total variable costs is the expense of temporary labor (day laborers) over $75 \%$ according to the obtained yield.

In conclusion, the greatest profit could be obtained by cultivating catnip.

Taking into account that medicinal plants are very suitable to organic growth and provided they are certified as, economic efficiency is the greatest in these conditions, due to higher price for valorizing their production (4-5 eur / kg) and higher subsidies granted 460 euros / ha in 2015.
\end{abstract}

Keywords: Agastache foeniculum, Nepeta cataria, Melissa officnalis, Lavandula angustifolia, economic efficiency.

\section{INTRODUCTION}

This paper is presenting the economic efficiency of four perrennial medicinal plant species grown for 7 years in the experimental field of Jucu, belonging to the University of Agricultural Sciences and Veterinary Medicine, Cluj-Napoca.

The four medicinal plant species studied are: giant hyssop (Agastache foeniculum), catnip (Nepeta cataria), lemon balm (Melissa officinalis) and lavender (Lavandula angustifolia), all perennial species belonging to family Lamiaceae.
Agastache foeniculum (Pursh) Kuntze belongs to the tribe Menthae, genus Agastache, sin. Brittonastrum, which includes about 30 species of aromatic perennial plant, among them the best known being: Agastache aurantiaca, A. Barberi (syn. Agastache pallida), A. cana, A. foeniculum, A. mexicana, A. rugosa, A. and A. urticifolia scrophulariifolia. Agastache foeniculum is the most frost-hardy of the agastache species.

In therapeutic purposes, mainly herba is used, against cardiovascular, nervous, gastrointestinal 
disease or as treatments for colds. It also has properties to prevent vomiting, antibacterial, antifungal and reduces the acid in the stomach. It relieves throat ache and symptoms of colds (Estrada-Reyes et al., 2004).

Nepeta cataria L. is cultivated for herba (shoots and flowering tops) containing 0.3 - 1\% of essential oils (nepetaloctone terpenoids), which can be extracted by steam distillation of water (Junwei et al., 2010). Catnip is a traditional remedy for colds and flu. Due to the carminative and antispasmodic actions, the plant relieves stomach disturbances, constipation, flatulence and colics. It is a perfect remedy for treating diarrhea in children. It also has anti-anxiety, antispasmodic, antitussive, astringent, carminative, diaphoretic, emmenagogue, nervine, refreshing, sedative, stomachic effect and tonic aperitif (http://www. pfaf.org).

Melissa officinalis L. is grown for leaves (Melissae folium) or the entire aerian part (Melissae herba), containing volatile oil (Muntean et al., 2007).

In terapeutic purpose is used in digestive disorders and vomiting, spasms, stomach and intestinal neurosis. Externally is used as baths, helping to heal wounds, having healing properties, antiseptics (Muntean et al., 2007).

Lavandula angustifolia Mill. is cultivated mainly for inflorescences (Lavandulae flos) used fresh or dried. In medicinal purpose, vegetal raw material of lavender has antispasmodic, carminative, analgesic, sedative, hypotensive, wound healing, antiseptic, antimicrobial, antifungal, antitussive, cholagogue, choleretic, diuretic, general tonic, cardiotonic action and tonic aperitif. It is considered one of the most tonics plants for the nervous system. Lavender tea removes headaches and insomnia. Externally it can be used for superficial wounds and burns, oral hygiene etc. (Muntean et al., 2007).

\section{MATERIALS AND METHODS}

In this paper we evaluated, from economically point of view, the profitability of those four crops studiated, in conditions of 2014 year, for two variants: the first year of vegetation and seventh year of vegetation. For both variants we weighed expenditure on maintenance, harvesting and conditioning the production, with the incomes earned through the sale of vegetal raw material.
Unlike the second variant, the first one includes also the costs of establishing the crops.

In market competition, to achieve an average profit, it is important to practice a competitive sale price, using in the process decision-making, opportunity costs.

In economic theory and practice, a special role has the opportunity cost. The opportunity cost is important to choose the most profitable crops depending on market demand. It allows us to place the crops and make the best choice of resources. For this we need to calculate the gross margin of each crop or species. Opportunity cost is synonymous with cost of production, as long as there is no monopoly control over resources.

Economic efficiency was established by calculating the following economic indicators :

- $\quad$ production realized per hectare - it was considered the production of dried herba

- $\quad$ production value - it was calculated based on the obtained yield and the average sales price; $\mathrm{V}=\mathrm{Q} \mathrm{t} \times \mathrm{Pv}$,

where:

$\mathrm{V}$ - value of comercial production;

$\mathrm{Pv}$ - the selling price per kilogram;

- $\quad$ average selling price - represents the average market price in each year;

- $\quad$ production cost - it is one of the indicators that characterizes the economic activity of an agricultural farm.

- $\quad$ the cost per unit of product represents the monetary expression of all charges of alive work done and materialized in the farm per unit of product (per kilogram of herba). This establishes reporting total production costs to total production achieved, namely:

$\mathrm{C}_{\mathrm{p}}=\frac{\sum \mathrm{Ch}}{\mathrm{Q}}$,

where:

$\mathrm{C}_{\mathrm{p}}$ - the production cost for one kilogram of herba;

$\mathrm{C}_{\mathrm{h}}^{\mathrm{p}}$ - total costs of production;

$\mathrm{Q}_{\mathrm{t}}$ - total production of herba.

- $\quad$ gross product - it is obtained by summing the value of production with subsidies, in the culture budget and to computers per hectare.

- gross margin - represents the difference between gross product (PB) obtained, and the proportional espenses (ChDP), which are also called variables, per unit area.

$\mathrm{MB}=\mathrm{PB}-\mathrm{ChDP}$ 
changing the gross margin (\%) - represents the percentage ratio between gross margin and gross margin witness (the first year of vegetation);

changing the cost per unit of product (\%) represents the percentage ratio between the cost per unit of product and the cost per unit of witness product (the first year of vegetation), (Merce Elena et al, 2009).

\section{RESULTS AND DISCUSSION}

Harvesting is done manually twice a year, with agricultural workers, usually daily basis, with an average tariff in the summer of 2014, 65 lei / day, which includes share (tax) $16 \%$ on income and CASS. Daily norm work / man set for hoeing and thinning is 0.15 ha; for harvesting vegetable raw material, $125 \mathrm{~kg}$ and $300 \mathrm{~kg}$ for conditioning. Conditioning (clean and dry) vegetable raw materials was made naturally, in the attic of a house.

Subsidies were granted under GD 863 / 07.10.2014. Payments are made in lei, at the exchange rate of 4,41 lei for one euro set by the European Central Bank on 30 September 2014 and published in the Official Journal of the European Union, Series C, no. 342 of October 1, 2014.

General management expenses were $0.35 \%$ of average variable costs for the four species. In establishing permanent labor costs took into account a percentage of the salary of an engineer, an accountant and a worker.

The selling price of a kilo of dried vegetal raw material was established like an average of market prices, taking into account the price offered by Plafar SA, S.C.D.A. Secuieni, online agricultural market and other companies of taking over vegetal raw material. Thus for giant hyssop it was 10,5 lei / kg, for catnip 10 lei / kg, for lemon balm 12 lei / $\mathrm{kg}$ and $20 \mathrm{lei} / \mathrm{kg}$ for lavender. For each specie, technological estimates of revenue and expenditure budgets were developed.

Tables 1 - 4 show, centralized, cost - benefit analysis of the four species studied for two variants: the first year of vegetation and seventh year of vegetation.

In the first year of vegetation largest share of total expenditure is represented by costs with seedlings and cuttings, between $79.88 \%$ and $90.21 \%$

Tab. 1. COST-BENEFIT ANALYSIS - variety Agastache foeniculum

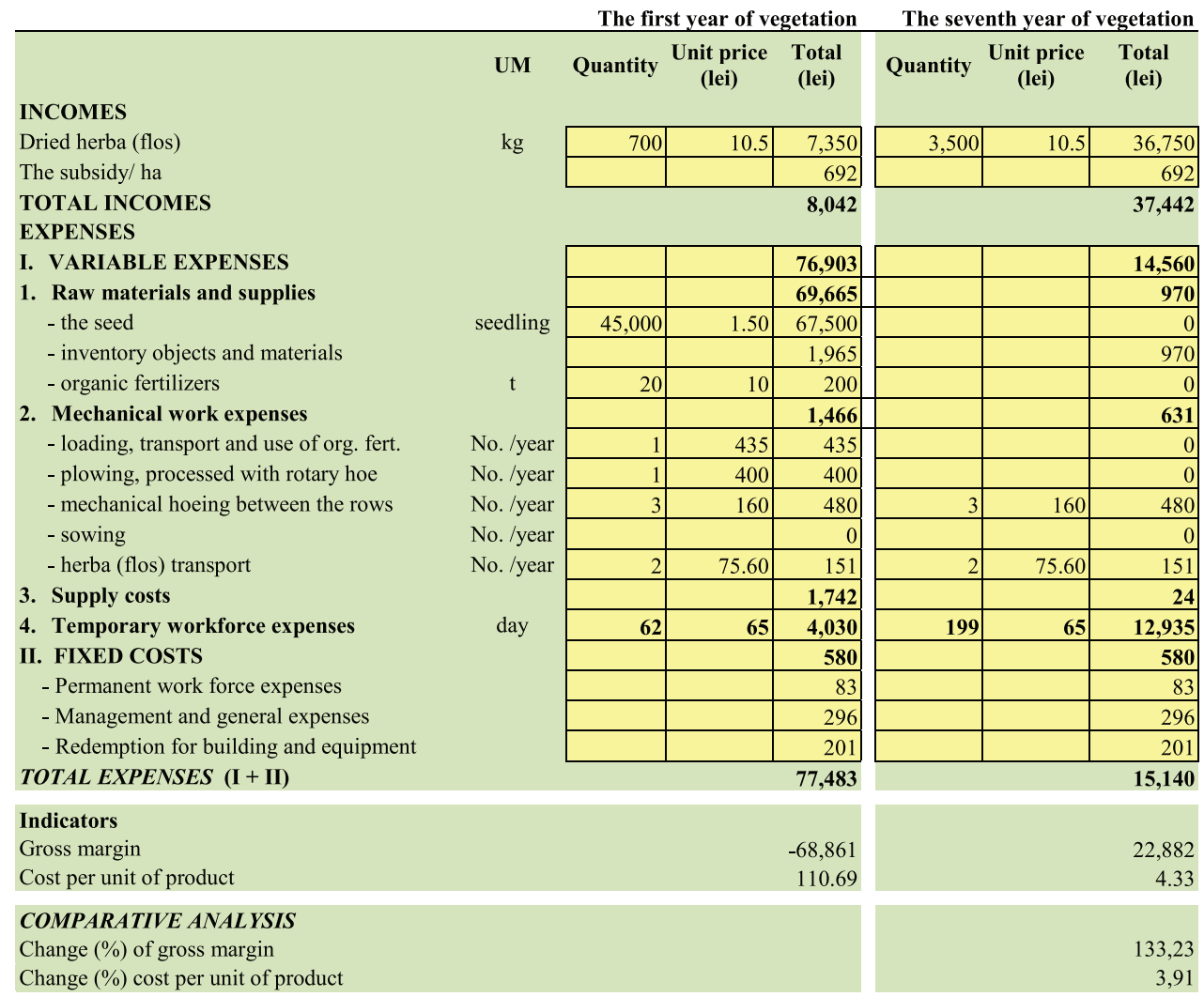


Tab. 2. COST-BENEFIT ANALYSIS - variety Nepeta cataria L.

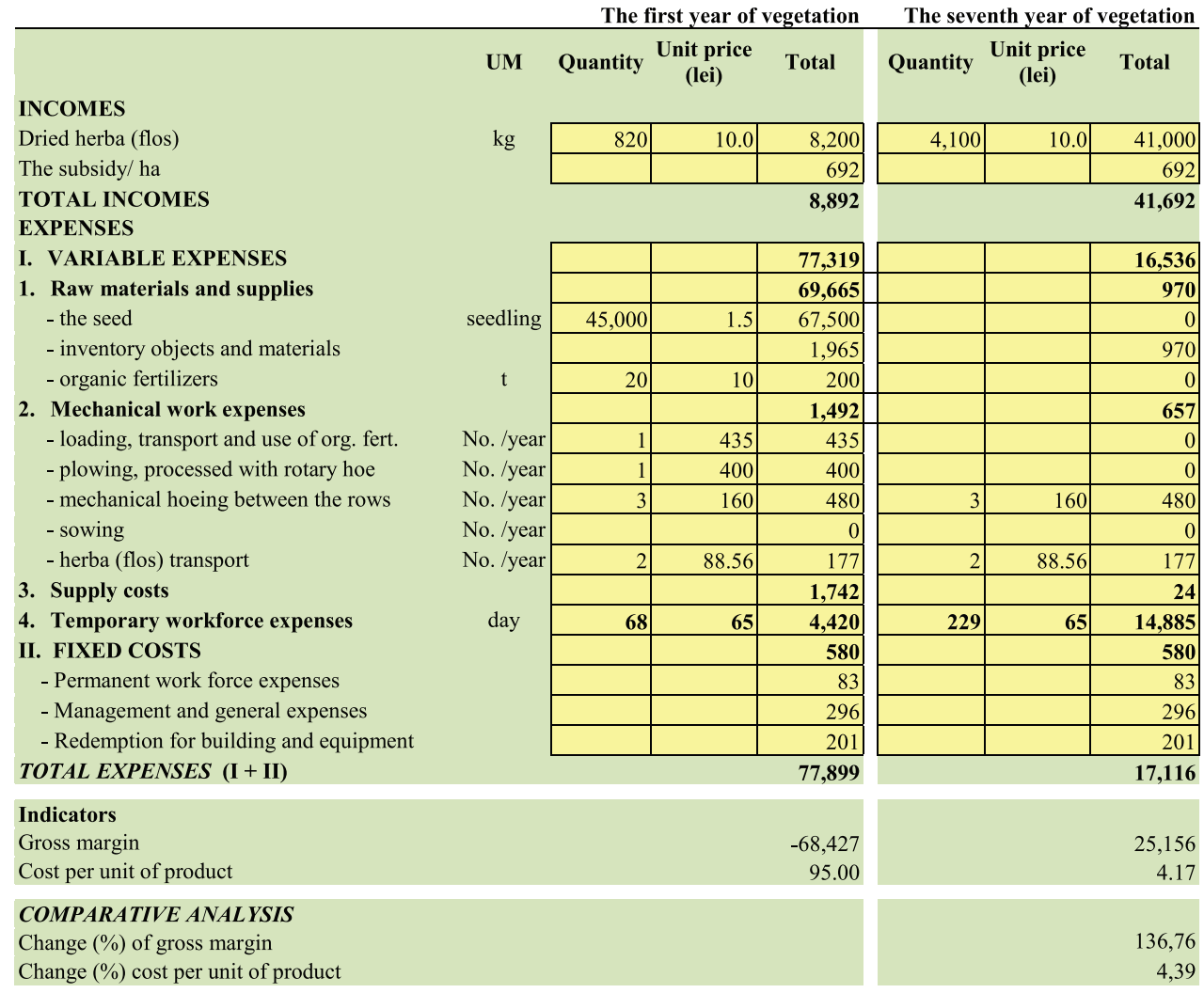

Tab. 3. COST-BENEFIT ANALYSIS - variety Melissa officinalis L.

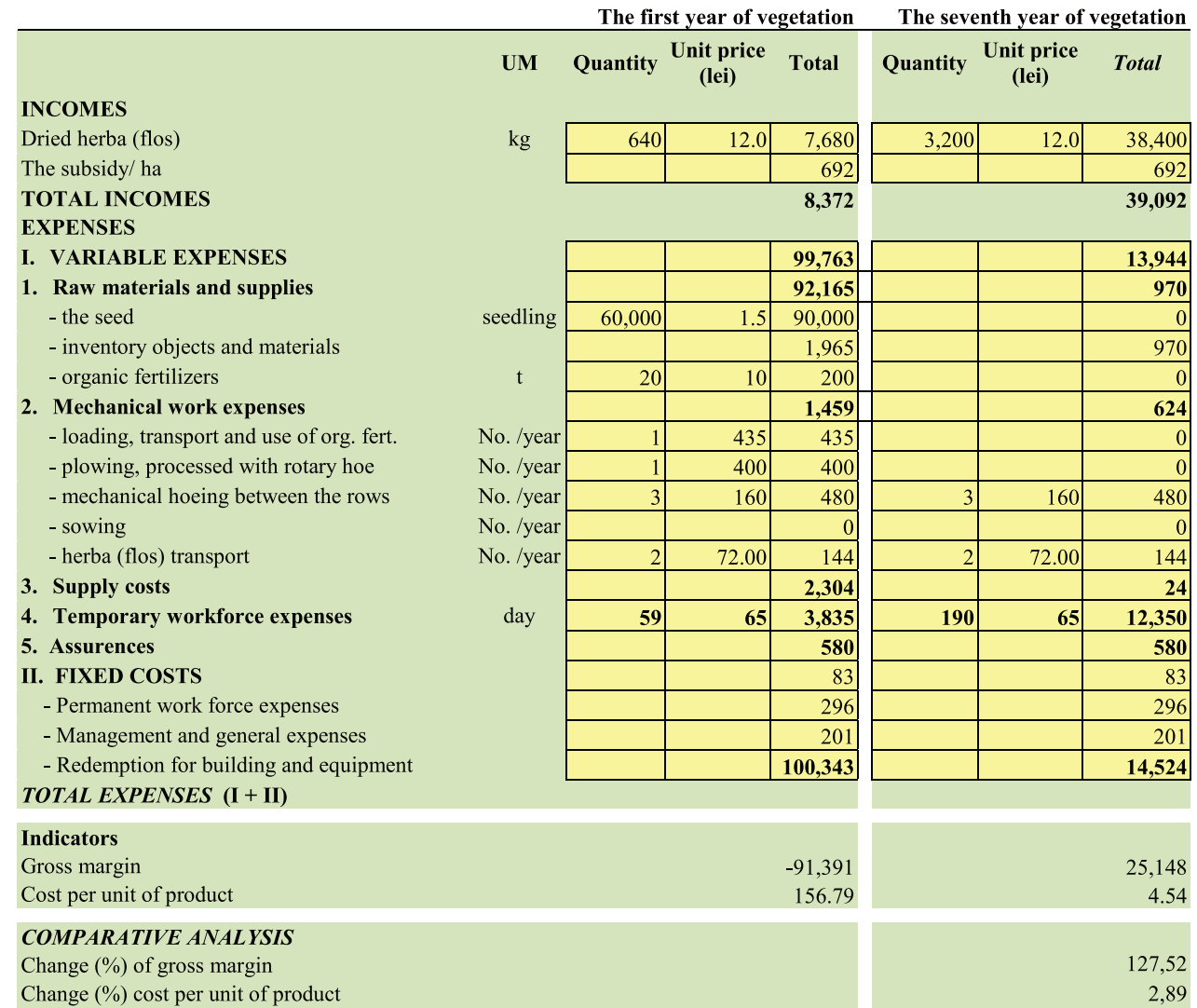


Tab. 4. COST-BENEFIT ANALYSIS - variety Lavandula angustifolia Mill.

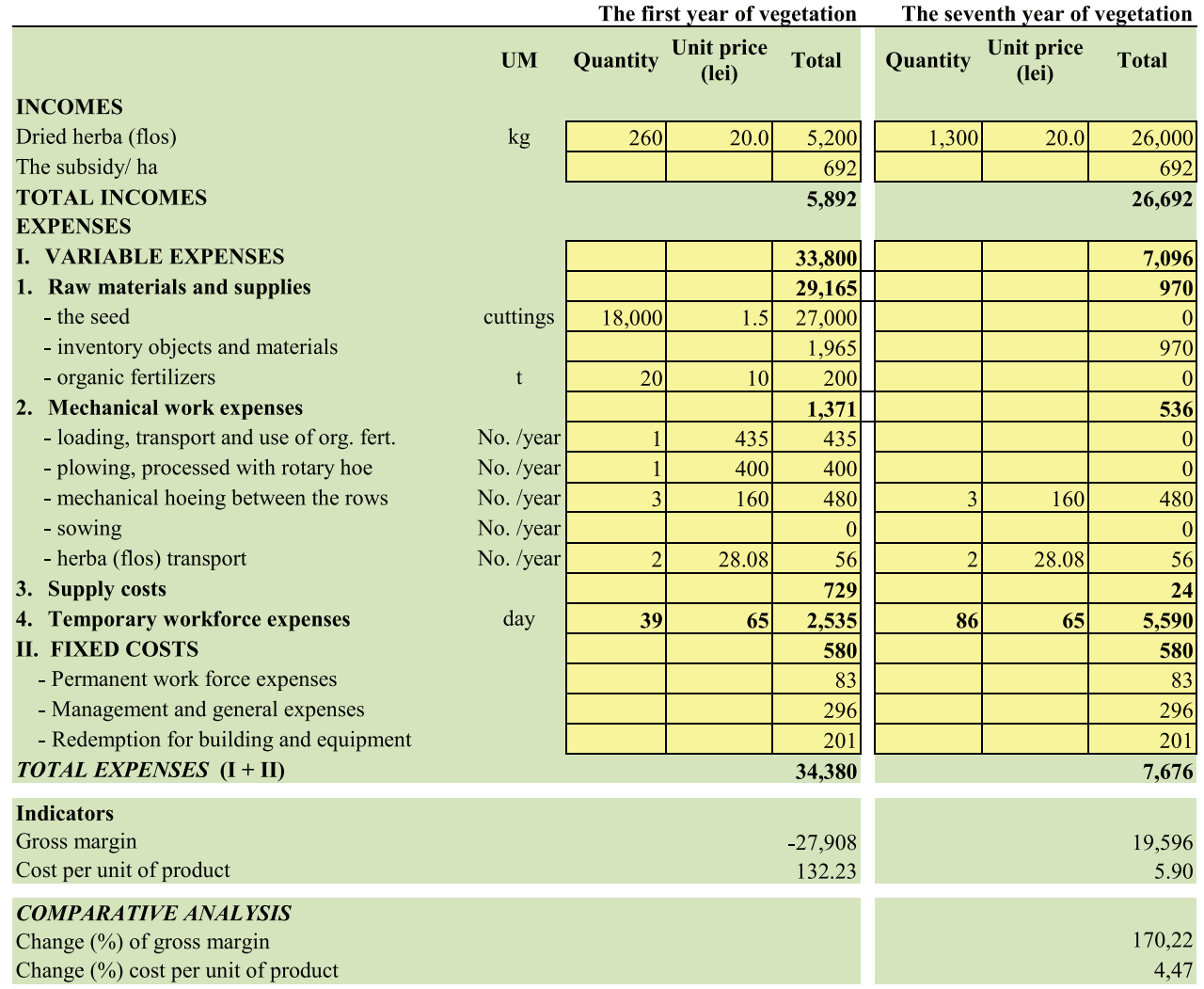

Tab. 5. SWOT analysis of cultivating the four species of medicinal plants

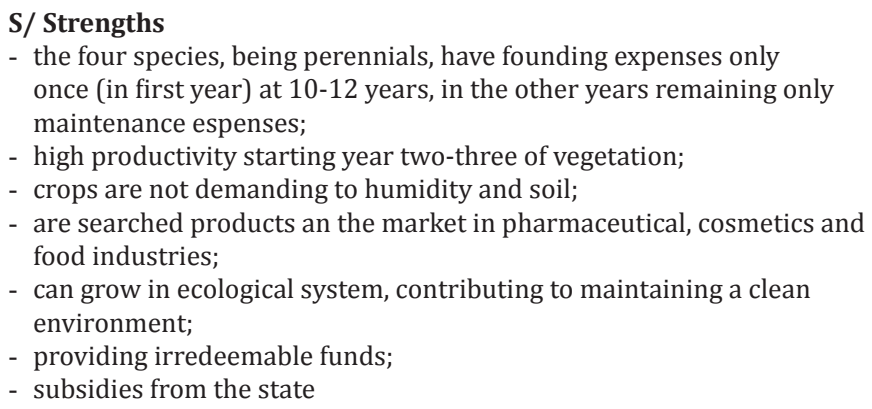

- the four species, being perennials, have founding expenses only once (in first year) at 10-12 years, in the other years remaining only maintenance espenses;

- high productivity starting year two-three of vegetation;

- crops are not demanding to humidity and soil;

- are searched products an the market in pharmaceutical, cosmetics and food industries;

- can grow in ecological system, contributing to maintaining a clean environment;

- providing irredeemable funds;

subsidies from the state

\section{0/ Opportunities}

- expanding market of selling, including export;

- the staff necessary to harvest does not require a higher qualification;

- through the new PNDR 2014-2020, the Ministry of Agriculture dedicated to the development of medicinal plants and aromatic, package 5 of the Measure 11 - Organic farming.

- increasing consumer preference for organic products.

\section{W/ Weak points}

- high costs with temporary work force;

- the rate of mechanization is reduced;

high costs of establishment culture;

difficulties relating to profitability almost nonexistent in the first year of vegetation

weak marketing system for these products.

\section{T/ Threats}

- Implementation of new standards (regarding the quality of production) increased production costs.
In the seventh year of vegetation it is found that the largest share of total variable costs is the temporary labor expense (day laborers) between $78.78 \%$ and $90.02 \%$ depending on the yields per hectare. The cost per unit of product varies between 4.17 and 5.90 lei / kg. Gross margin (MB) is estimated at $19.596-25.156$ lei / ha depending on the species.

After doing the experience and capitalizing the obtained production, it can be performed a SWOT analysis (Table 5) of cultivating the four medicinal plants in ecological system. 


\section{CONCLUSION}

SWOT analysis shows that there are several strengths and opportunities to develop and encourage farmers to invest in the cultivation of medicinal and aromatic plants. To improve and develop the sector, weaknesses and threats for each case should be considered.

The higher primary cultivation costs are at the species Melissa officinalis L. due to more seedlings required per hectare. The cost per unit of output in seven vegetation descrease by more than $90 \%$ from the first year.

Founding crop costs are recovered from the year 3-4, depending on the species.

The highest profit was achieved in the case of Nepeta cataria L. species, due to higher production per hectare, but the biggest demand on the market was for Lavandula angustifolia Mill species.

Given that medicinal plants are very suitable to grow organically, provided they are certified, economic results would be much better if the production were sold with the label "organic" due to higher price offered (4 - 5 eur / kg) and higher subsidies granted 350 euros in 2015 , according to the PNDR 2014-2020.

Acknowledgments. This paper was published under the frame of European Social Fund, Human Resources Development Operational Programme 2007-2013, project no. POSDRU/159/1.5/S/ 132765 and was partly financially supported by the project Partnerships in Priority Areas Programme - PN II, developed with the support of MEN - UEFISCDI, project no. 148/2014 and POS CCE projectRoBeeTech, no. 206/2010.

\section{REFERENCES}

1. Estrada-Reyes Rosa, Eva Aguirre Hernandez, Aida GarciaArgaez, Marcos Soto Hernandez, Edelmira Linares, Robert Bye, Gerardo Heinze, Mariano Martinez-Vazquez (2004). Comparative chemical composition of Agastache mexicana subsp. mexicana and A. mexicana subsp. xolocotziana. Biochemical Systematics and Ecology 32: 685-694.

2. Junwei J. Zhu, Christopher A. Dunlap, Robert W. Behle, Dennis R. Berkebile, Brian Wienhold. (2010). Repellency of a wax-based catnip-oil formulation against stable flies. Journal of Agricultural and Food Chemistry, 58 (23): 12320-12326.

3. Merce Elena, Cristina Bianca Pocol (2009). Economie Rurală, Ed. AcademicPres, Cluj-Napoca.

4. Muntean, L.S., M. Tămaș, S. Muntean, L. Muntean, M.M. Duda, D.I. Vârban, S. Florian (2007). Tratat de plante medicinale cultivate şi spontane, Ed. Risoprint Cluj-Napoca, 928 p, ISBN 978-973-751-463-9.

5. HG 863/7.10.2014, Hotărâre privind stabilirea pentru anul 2014 a cuantumului plăților directe unice pe suprafață, plăților separate pentru zahăr şi plăților specifice pentru orez, care se acordă în agricultură în sectorul vegetal, publicată în M.O. 745/13.10. 2014.

6. Programului Național de Dezvoltare Rurală (2014 - 202), www.madr.ro

7. www.pfaf.org

8. www.piata-agricola.ro

9. www.scda.ro 